\title{
BROMOPYRROLE ALKALOIDS FROM THE CARIBBEAN SPONGE Agelas cerebrum
}

Erik L. Regalado* and Abilio Laguna

Department of Chemistry, Center of Marine Bioproducts, Loma y 37, Alturas del Vedado, C.P. 10400 Havana, Cuba Judith Mendiola

Department of Parasitology, Institute of Tropical Medicine "Pedro Kourî" (IPK), Autopista Novia del Mediodía km 61², PO Box 601, Marianao 13, Havana, Cuba

\section{Olivier P. Thomas}

Université de Nice-Sophia Antipolis, Laboratoire de Chimie des Molécules Bioactives et des Arômes, UMR 6001 CNRS, Institut de Chimie de Nice, Faculté des Science, Parc Valrose, 06108 Nice Cedex 02, France

\section{Clara Nogueiras}

Center of Natural Products, Faculty of Chemistry, University of Havana, San Lázaro y L, Havana, Cuba

Recebido em 25/6/10; aceito em 20/9/10; publicado na web em 8/12/10

\begin{abstract}
Bioguided fractionation of Agelas cerebrum crude extract resulted in isolation of four bromopyrrole and four bromopyrrole aminoimidazole alkaloids, identified as 5-bromopyrrole-2-carboxylic acid (1), 4-bromopyrrole-2-carboxylic acid (2), 3,4-bromopyrrole-2-carboxylic acid (3), 4,5-bromopyrrole-2-carboxylic acid (4), oroidin (5), bromoageliferin (6), dibromoageliferin (7) and dibromosceptrin (8) on the basis of spectroscopic data analyses (UV, IR, HRMS, 1D and 2D NMR) and comparison with literature data. This is the first report of compounds $\mathbf{2}$ and $\mathbf{3}$ in a marine sponge belonging to the Agelas genus and the first evidence of the presence of $\mathbf{1}$ from a natural source.
\end{abstract}

Keywords: Agelas cerebrum; bromopyrrole alkaloids; antitumoral and antiprotozoal activity.

\section{INTRODUCTION}

Interest in the biology and chemistry of sponges that belong to the genus Agelas continues despite many years of study devoted to these species. Agelas sponges are commonly found on the Caribbean and Indo-Pacific coral reefs, and new species are reported every year. For example, in 1992 it was noted that 12 species of Agelas were documented, ${ }^{1}$ while today the taxonomic record shows that there are 35 such species, ${ }^{2}$ from which more than 200 novel molecules have been isolated, ${ }^{3}$ some of them with high therapeutic potential. ${ }^{4}$

Characteristic metabolites from this genus of sponges are bromopyrrole alkaloids which present a broad range of biological activities, ${ }^{5}$ including anticancer ${ }^{6}$ and antimalarial activity. ${ }^{7}$ Structurally, most of them are built up by a 4-bromo- or 4,5-dibromopyrrole-2-carboxylic acid moiety, which is often connected with a 2-aminoimidazole group through an aliphatic segment. Monomers of this chemotype can dimerize or trimerize to give a large variety of pyrrole 2-aminoimidazole alkaloids.

As part of our ongoing work on secondary metabolites produced by Caribbean marine sponges, we undertook the chemical study of the marine sponge Agelas cerebrum Assmann, van Soest \& Köck, 2001 (phylum Porifera, class Demospongiae, order Agelasida, family Agelasidae). This is the first report of a chemical study on the isolation and identification of metabolites from the marine sponge A. cerebrum.

\section{EXPERIMENTAL}

\section{General procedures}

UV measurements were performed on a Varian Cary 300 Scan

*e-mail: erikluis18@gmail.com
UV-visible spectrophotometer. IR spectra were obtained with a PerkinElmer Paragon 1000 FT-IR spectrophotometer. NMR experiments were performed on a Bruker Avance $500 \mathrm{MHz}$ spectrometer. Low resolution electrospray ionization (ESI) mass spectra were obtained with a Bruker Esquire 3000 Plus spectrometer in the positive or negative mode. High resolution mass spectra (HRESIMS) were conducted on a LTQ Orbitrap mass spectrometer (Thermo Finnigan). HPLC purification was carried out on a Waters 600 system equipped with a Waters 717 plus autosampler, a Waters 996 photodiode array detector, and a Sedex 55 evaporative light-scattering detector (Sedere, France).

\section{Biological material}

A specimen of the marine sponge A. cerebrum was collected at a depth of about $20 \mathrm{~m}$ from "Boca de Calderas", Havana, Cuba (23 05' 55" N 82 28' 30" W) in March 2008 and identified by Dr. P. M. Alcolado (Institute of Oceanology, Havana, Cuba). A voucher sample (ANC.02.010) has been deposited in the sponge collection of the Cuban National Aquarium. The sponge was kept frozen from collection until the extraction process.

\section{Extraction and isolation}

A portion of A. cerebrum (250 g) was freeze-dried and ground to obtain a dry powder $(15 \mathrm{~g})$, which was exhaustively extracted with a mixture of $\mathrm{MeOH} / \mathrm{CH}_{2} \mathrm{Cl}_{2}(1: 1)$ to give $2.3 \mathrm{~g}$ of a crude extract after concentration under reduced pressure. The crude extract was fractionated by $\mathrm{RP}_{-} \mathrm{C}_{18}$ flash chromatography (elution with a decreasing polarity gradient of $\mathrm{H}_{2} \mathrm{O} / \mathrm{MeOH}$ from $1: 0$ to $0: 1$, then $\mathrm{MeOH} / \mathrm{CH}_{2} \mathrm{Cl}_{2}$ from 1:0 to 0:1). Fractions obtained were submitted to antitumoral assays by a colorimetric high-throughput screen. 
The bioactive $\mathrm{H}_{2} \mathrm{O} / \mathrm{MeOH}(1: 3)$ fraction $(180 \mathrm{mg}$ ) was chosen for a chemical investigation and was further fractionated by $\mathrm{RP}-\mathrm{C}_{18}$ semi-preparative HPLC (Phenomenex, Luna $\mathrm{C}_{18}, 250 \times 10 \mathrm{~mm}, 5$ $\mu \mathrm{m})$ with a gradient of $\mathrm{H}_{2} \mathrm{O} / \mathrm{MeOH} /$ Formic acid from 60:40:0.1 to 20:80:0.1 in $35 \mathrm{~min}$ (flow $3.0 \mathrm{~mL} / \mathrm{min}$ ) and the subsequent mixtures were finally purified by $\mathrm{RP}-\mathrm{C}_{18}$ analytical HPLC (Phenomenex Luna $\mathrm{C}_{18}, 150 \times 4.6 \mathrm{~mm}, 5 \mu \mathrm{m}$, flow $1.0 \mathrm{~mL} / \mathrm{min}$ ) to afford a new compound $(\mathbf{1}, 1.2 \mathrm{mg})$, together with seven known metabolites: $\mathbf{2}$ (5.2 mg), 3 (1.0 mg), 4 (2.5 mg), 5 (3.6 mg), 6 (2.7 mg), 7 (1.8 mg) and $\mathbf{8}(1.4 \mathrm{mg})$. Due to higher yield requirements for antimalarial assays, a preparative fraction was further obtained by $\mathrm{RP}_{-} \mathrm{C}_{18}$ chromatography after stepwise elution with $\mathrm{H}_{2} \mathrm{O}$ (which was discarded) and $\mathrm{MeOH} / \mathrm{CH}_{2} \mathrm{Cl}_{2}(1: 1)$.

Compound 1: Amorphous white solid; UV (MeOH) $\lambda_{\max }$ (log ع) 234 (3.80), $273(4.10) \mathrm{nm}$; IR (thin film) $v_{\max } 3356,3122,1649$ $\mathrm{cm}^{-1}$; ${ }^{1} \mathrm{H}$ NMR $\left(500 \mathrm{MHz}, \mathrm{CD}_{3} \mathrm{OD}+\mathrm{CDCl}_{3}\right) \delta 6.26(1 \mathrm{H}, \mathrm{d}, J=$ $3.5 \mathrm{~Hz}, \mathrm{H}-4), 6.59$ (1H, d, $J=3.5 \mathrm{~Hz}, \mathrm{H}-3) ;{ }^{13} \mathrm{C} \mathrm{NMR}(125 \mathrm{MHz}$, $\left.\mathrm{CD}_{3} \mathrm{OD}+\mathrm{CDCl}_{3}\right) \delta 129.3(\mathrm{C}-2), 111.7(\mathrm{C}-3), 112.3(\mathrm{C}-4), 104.3$ (C-5), 164.1 (C-6); HRESI-MS (-): m/z 190, 188 [M-H] ' (calcd for $\left.\mathrm{C}_{5} \mathrm{H}_{3}{ }^{79} \mathrm{BrNO}_{2}, 187.9396, \Delta 0.3 \mathrm{ppm}\right)$.

\section{Antitumoral assay}

A colorimetric assay using sulforhodamine B was adapted for a quantitative measurement of cell growth and viability following a technique described in the literature. ${ }^{8}$ In Vitro cytotoxicity was evaluated against three tumor cell lines: lung carcinoma A549, colon carcinoma HT29, and breast MDA-MB-231 and samples were tested at concentrations of 100,10 and $1 \mu \mathrm{g} / \mathrm{mL}$.

\section{Antimalarial assay}

In vitro drug susceptibility was determined in standard shortterm cultures of Plasmodium berghei ANKA blood stages, as described before. ${ }^{9}$ Briefly, erythrocytes infected with parasites of $P$. berghei ring forms/young trophozoites were incubated at $2 \%$ parasitemia at a final cell concentration of $1 \%$ in complete culture medium (RPMI 1640; 20\% Fetal Calf Serum, Sigma) containing serial dilutions of samples from $A$. cerebrum, each in duplicate wells of 96-well culture plates. These plates were incubated for a period of $24 \mathrm{~h}$ at $37^{\circ} \mathrm{C}$ under standardized in vitro culture conditions. The antimalarial activity was expressed as $\mathrm{IC}_{50}$, which was determined according to reported methodology ${ }^{10}$ using data of inhibition of schizont maturation measured as described by Schlichtherle et al. ${ }^{11}$ and adapting recommendations for $P$. falciparum isolates. ${ }^{12}$ Chloroquine phosphate and artemisinin (both from Sigma) were used as references.
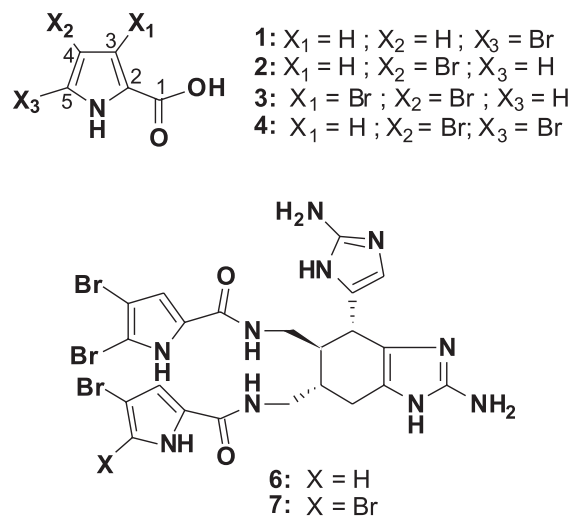

\section{RESULTS AND DISCUSSION}

Compound 1 was isolated as amorphous white solid and its mass spectrum showed molecular ions at $\mathrm{m} / \mathrm{z} 188$ and 190 in a 1:1 ratio, indicative of the presence of one bromine atom. The molecular formula was determined as $\mathrm{C}_{5} \mathrm{H}_{4} \mathrm{NO}_{2} \mathrm{Br}$ by HRESI-MS. The UV absorption $\left[\lambda_{\max } 273 \mathrm{~nm}(\log \varepsilon 4.10)\right]$ was attributed to a substituted pyrrole chromophore. ${ }^{13}$ The bands at 3356,3122 , and $1649 \mathrm{~cm}^{-1}$ in the IR spectrum suggested the presence of amine and carbonyl moieties. In the ${ }^{13} \mathrm{C}$ NMR spectrum, resonances due to a disubstituted pyrrole at $\delta 104.3$ (s), $112.3(\mathrm{~d}), 111.7(\mathrm{~d})$, and 129.3 (s) were observed as well as a carbonyl $(\mathrm{COOH})$ at $\delta 164.1$ (s). The ${ }^{1} \mathrm{H}$ NMR spectrum indicated resonances due to 2,5-disubstituted pyrrole protons at $\delta$ $6.26(1 \mathrm{H}, \mathrm{d}, J=3.5 \mathrm{~Hz}, \mathrm{H}-4)$ and $6.59(1 \mathrm{H}, \mathrm{d}, J=3.5 \mathrm{~Hz}, \mathrm{H}-3)$. The positions of the $\mathrm{CO}_{2} \mathrm{H}$ moiety at $\mathrm{C}-2$ and the bromine atom at $\mathrm{C}-5$ were in agreement with other 2,5-disubstituted pyrroles. ${ }^{14}$ On this basis, compound 1 was concluded to be 5-bromopyrrole-2-carboxylic acid. On the other hand, compounds $\mathbf{2 - 8}$ were identified by a combination of spectroscopic methods $\left({ }^{1} \mathrm{H},{ }^{13} \mathrm{C} 1 \mathrm{D}\right.$ and $2 \mathrm{D}$ NMR, ESIMS $)$ and comparison with the literature data.

Bromopyrrole alkaloids are known to be one of the most common metabolites contained in marine sponges ${ }^{15}$ and they are widely distributed in the species belonging to the genera Agelas, Axinella, Acanthella, Pseudoaxinyssa, and Hymeniacidon. ${ }^{16}$ Oroidin (5), the first member of pyrrole-2-aminoimidazole alkaloids in this group, was isolated from the sponge $A$. oroides.$^{17}$ However, a revised structure was soon proposed. ${ }^{18}$ It was not until 1981, during solidstate photodimerization studies of (-)-sceptrin, a related dimeric bromopyrrole alkaloid, that the final structure of $\mathbf{5}$ was confirmed by X-ray diffraction analysis. ${ }^{19}$ Oroidin has been isolated from many Agelas sponges and species of other genera such as: Axinella damicornis, Axinella verrucosa, Acanthella aurantiaca, Goreauiella sp and Pseudaxinyssa cantharella ${ }^{20}$ Compound 4 (4,5-bromopyrrole-2-carboxylic acid) has been also isolated from many Agelas species and together with oroidin have been reported to exhibit significant biological properties. ${ }^{21}$ Chanas et al. ${ }^{22}$ suggested that $A$. conifera, A. dispar, A. inaequalis, $A$. sceptrum and $A$. wiedenmmeri share both metabolites as a common chemical defense against fish predators.

Bromoageliferin (6) and dibromoageliferin (7), dimers of oroidin, were isolated from A. conifera and A. cf. mauritiana. ${ }^{23}$ These metabolites are potent actomyosin ATPase activators ${ }^{24}$ and other significant biological effects have been reported. ${ }^{25}$ Since then, these compounds have been isolated from many Agelas species and from sponges of other genera such as Astroscera willeyana ${ }^{26}$ and Stylissa caribica. ${ }^{27}$ Dibromosceptrin $(\mathbf{8})$, another dimeric bioactive metabolite, belonging to the sceptrin family, was discovered in A. conifera. ${ }^{20}$ This compound, as well as $\mathbf{6}$ and $\mathbf{7}$, were found to be potent feeding deterrents. ${ }^{28}$<smiles>Nc1ncc(/C=C/CNC(=O)c2cc(Br)c(Br)[nH]2)[nH]1</smiles><smiles>Nc1ncc(C2[C@@H](CNC(=O)c3cc(Br)c(Br)[nH]3)C(CNC(=O)c3cc(Br)c(Br)[nH]3)[C@@H]2c2cnc(N)[nH]2)[nH]1</smiles>

Figure 1. Structures of compounds 1-8 isolated from A. cerebrum 
4-Bromopyrrole-2-carboxylic acid (2) and 3,4-bromopyrrole-2carboxylic acid (3) were recently encountered in the Mediterranean sponge Axinella verrucosa $a^{29}$ and the tropical sponge Axinella damicornis. ${ }^{6}$ However, to our knowledge, this is the first report of the occurrence of both compounds in a sponge belonging to the Agelas genus. While compound $\mathbf{1}$ had been previously synthesized, ${ }^{28}$ it is herein reported as a new natural bromopyrrole alkaloid isolated from this species. 5-bropyrrole alkaloids are not commonly isolated from marine sources and there are only two examples of other new 5-bromopyrrole derivatives identified in the genus Agelas. ${ }^{30}$ Then, in a sense, compound 1 may be useful as a chemotaxonomic marker for Agelas cerebrum.

Concerning bioactivity, the $\mathrm{H}_{2} \mathrm{O} / \mathrm{MeOH}$ (1:3) fraction from which compounds 1-8 were isolated showed strong cytotoxic activity in an in vitro antitumoral assay against three human tumor cell lines (A549 lung cancer cells, HT29 colonic cancer cells, and MDA-MB-231 breast cancer cells) at values equal and greater than $1 \mu \mathrm{g} / \mathrm{mL}$; however, no antitumor activity against the same cell lines was detected below $10 \mu \mathrm{g} / \mathrm{mL}$ for each isolated compound. Probably, undetectable quantities of a very potent antineoplastic substance justify the activity of the crude fraction, or the synergism of natural product mixtures.

The organic extract of A. cerebrum exhibited a moderate antimalarial activity, which was evaluated according to recommended endpoint criteria for natural complex mixtures,${ }^{31}$ with $\mathrm{IC}_{50}$ value equal to 60,35 $\pm 10,6 \mu \mathrm{g} \mathrm{x} \mathrm{mL}{ }^{-1}$ against $P$. berghei. Although this work revealed a different profile for bromopyrrole alkaloids isolated from $A$. cerebrum in comparison to that previously described for $A$. oroides, the presence of oroidin (5) and 4,5 dibromopyrrole-2-carboxilic acid (4) suggests that they are the main active principles in the antimalarial organic fraction. Both compounds were previously identified in $A$. oroides as devoid of any cytotoxicity against L6 cells, while they exhibited an $\mathrm{IC}_{50}$ value of $3.9 \mathrm{mg} / \mathrm{ml}$ for $\mathbf{4}$ and a limited antimalarial activity for $\mathbf{5}$, in the whole cell parasite assays. ${ }^{7}$ Sceptrin was evaluated against D6 and W2 strains by other authors and showed no activity. ${ }^{32}$

In conclusion, this chemical study underscores the presence of bromopyrrole alkaloids as the representative secondary metabolites of Agelas cerebrum, and contributes to the chemotaxonomy within the Agelasidae family. Studies are in progress in order to advance the evaluation of the in vivo antimalarial activity of bromopyrrole alkaloids from Agelas cerebrum.

\section{ACKNOWLEDGEMENTS}

Financial support was provided by the French ANR Biodiversité 2006 (ECIMAR project, www.ecimar.org) and the research grant No. 4500045956 of IOC/UNESCO 2008 (E. L. R and O. P. T). We are also grateful to Boehringer Ingelheim Fonds for financial support provided by a fellowship (E. L. R) in April 2008. The authors thank Dr. P. M. Alcolado (Institute of Oceanology, Havana, Cuba) for careful taxonomical sponge identification, Dr. M. Gaysinski and the PFTC of Nice for assistance in recording the NMR spectroscopic experiments and PharmaMar Madrid for antitumor screening.

\section{REFERENCES}

1. Braekman, J. C.; Daloze, D.; Stoller, C.; van Soest, R. W. M.; Biochem. Syst. Ecol. 1992, 20, 417.

2. van Soest, R.; Boury-Esnault, N.; Janussen, D.; Hooper, J.; World Porifera database. In http://www.marinespecies.org/porifera/porifera. php?p=taxlist.html, accessed January 2010.

3. Munro, M. H. G.; Blunt, J. W.; Marine Literatura DataBase (MarinLit), University of Canterbury, New Zealand, 2009.

4. Costa-Lotufo, L. V.; Wilke, D. V.; Jimenez, P. C.; Epifanio, R. de A.; Quim. Nova 2009, 32, 703.
5. Mayer, A. M.; Rodriguez, A. D.; Berlinck, R. G.; Hamann, M. T.; Comp. Biochem. Physiol., C: Comp. Pharmacol. Toxicol. 2007, 145, 553; Mayer, A. M.; Rodriguez, A. D.; Berlinck, R. G.; Hamann, M. T.; Biochim. Biophys. Acta 2009, 1790, 283.

6. Hassan, W.; Elkhayat, E. S.; Edrada, R. A.; Ebel, R.; Proksch, P.; Nat. Prod. Commun. 2007, 21, 1149; Hertiani, T.; Edrada-Ebel, R.; Ortlepp, S.; van Soest, R. W. M.; de Voogd, N. J.; Wray, V.; Hentschel, U.; Kozytska, S.; Müller, W. E. G.; Proksch, P.; Bioorg. Med. Chem. 2010, 18, 1297.

7. Tasdemir, D.; Topaloglu, B.; Perozzo, R.; Brun, R.; O'Neill, R.; Carballeira, N. M.; Zhang, X.; Tonge, P. J.; Linden, A.; R edi, P.; Bioorg. Med. Chem. 2007, 15, 6834; Fattorusso, E.; Taglialatela-Scafati, O.; Mar. Drugs 2009, 7, 130 .

8. Skehan, P.; Storeng, R.; Scudiero, D.; Monks, A.; McMahon, J.; Vistica, D.; Warren, J. T.; Bokesch, H.; Kenney, S.; Boyd, M. R.; J. Natl. Cancer Inst. 1990, 82, 1107.

9. Janse, C. J.; Waters, A. P.; Parasitol. Today 1995, 11, 138.

10. Huber, W.; Koella, J. C.; Acta Trop. 1993, 55, 257.

11. Schlichtherle, M.; Wahlgren, M.; Perlmann, H.; Scherf, A.; Methods in malaria research, $3^{\text {rd }}$ ed., Malaria Research and Reference Reagent Resource Center: Virginia, 2000.

12. World Health Organization, Expert Committee. In vitro micro-test (Mark III) for the assessment of the response of Plasmodium falciparum to chloroquine, mefloquine, quinine, amodiaquine, sulfadoxine/pyrimethamine and artemisinin; CTD/MAL/97.20 Rev.2.2001.

13. Araki, A.; Kubota, T.; Aoyama, K.; Mikami, Y.; Fromont, J.; Kobayashi, J.; Org. Lett. 2009, 11, 1785.

14. Cimino, G.; De Rosa, S.; De Stefano, S.; Mazzarella, L.; Puliti, R.; Sodano, G.; Tetrahedron Lett. 1982, 23, 767; Nakamura, H.; Ohizumi, Y.; Kobayashi, J.; Hirata, Y.; Tetrahedron Lett. 1984, 25, 2475.

15. Blunt, J. W.; Copp, B. R.; Hu, W.-P.; Munro, M. H. G.; Northcote, P. T.; Prinsep, M. R.; Nat. Prod. Rep. 2008, 25, 35.

16. Faulkner, D. J.; Nat. Prod. Rep. 2000, 17, 7; Erpenbeck, D.; van Soest, R. W. M.; Biochem. Syst. Ecol. 2005, 33, 585.

17. Forenza, S.; Minale, L.; Riccio, R.; Fattorusso, E.; J. Chem. Soc., Chem. Commun. 1971, 1129

18. Garcia, E. E.; Benjamin, L. L.; Fryer, R. I.; J. Chem. Soc., Chem. Commun. 1973, 78 .

19. Walker, R. P.; Faulkner, D. J.; van Engen, D.; Clardy, J.; J. Am. Chem. Soc. 1981, 103, 6772 .

20. Keifer, P. A.; Schwartz, R. E.; Koker, M. E. S.; Hughes, R. G., (Jr); Rittschof, D.; Rinehart, K. L.; J. Org. Chem. 1991, 56, 2965.

21. Bickmeyer, U.; Drechsler, C.; Köck, M.; Assmann, M.; Toxicon 2004, 44,45 .

22. Chanas, B.; Pawlik, J. R.; Lindel, D.; Fenical, W.; J. Exp. Mar. Biol. Ecol. 1996, 208, 185.

23. Rinehard, K. L.; Pure Appl. Chem. 1989, 61, 525.

24. Kobayashi, J.; Tsuda, M.; Tetrahedron 1990, 46, 5579.

25. Huigens, R. W.; Richards, J. J.; Parise, G.; Ballard, T. E.; Zeng, W.; Deora, R.; Melander, C.; J. Am. Chem. Soc. 2007, 129, 6966.

26. Williams, D. H.; Faulkner, D. J.; Tetrahedron 1996, 52, 5381.

27. Assmann, M.; van Soest, R. W. M.; Köck, M.; J. Nat. Prod. 2001, 64, 1345.

28. Assmann, M.; Lichte, E.; Pawlik, J. R.; Köck, M.; Mar. Ecol. Prog. Ser. 2000, 207, 255.

29. Aiello, A.; D’Esposito, M.; Fattorusso, E.; Menna, M.; Mueller, W. E. G.; Perović-Ottstadt, S.; Schröeder, H. C.; Bioorg. Med. Chem. 2006, 14,17 .

30. Iwagawa, T.; Kaneko, M.; Okamura, H.; Nakatani, M.; van Soest, R. W. M.; J. Nat. Prod. 1998, 61, 1310.

31. Cos, P.; Vlietinck, A. J.; Vanden Berghe, D.; Maes, L.; J. Ethnopharmacol. 2006, 106, 290.

32. Mohammed, R.; Peng, J.; Nelly, M.; Hamann, M. T.; J. Nat. Prod. 2006, 69, 1739. 